\title{
Penerapan Pendekatan Saintifik Dalam Pengembangan Keterampilan Motorik Anak di TK Al-Kautsar Indralaya Ogan Ilir
}

\author{
Meriatul Kibtiyah \\ Fakultas Tarbiyah dan Ilmu Keguruan \\ Universitas Islam Negeri Raden Fatah Palembang \\ Email: merykibtiyah@yahoo.co.id
}

\begin{abstract}
Abstrak: Keterampilan motorik kasar dan halus anak pada pembelajaran di TK Al Kautsar Indralaya Ogan Ilir sebagai fokus penelitian bertolak dari kenyataan di lapangan bahwa proses pembelajaran di TK tersebut belum tergarap secara bersamaan. Proses pembelajaran hanya terkonsetrasi pada aspek kognitif, bahkan keterampilan tersebut belum maksimal dicapai oleh anak. Akibatnya, di satu sisi kurang terampil dalam kegiatan motorik kasar dan halus. Maka diperlukan pendekatan saintifik alternatif yang dapat menyetuh pencapaian aspek keterampilan motorik kasar maupun motorik halus. Penelitian ini bertujuan untuk mengetahui perbedaan keterampilan motorik kasar dan halus anak antara kelas ekperimen dan kelas kontrol baik sebelum maupun setelah proses pembelajaran anak di TK Al Kautsra Indralaya Ogan Ilir untuk mewujudkan tujuan penelitian tersebut digunakan penelitian Quasi Experimental Design Nonequivalent Control Group Design. Dalam pelaksanaannya treatment yakni Penerapan Pendekata Saintifik, diberikan kepada anak kelas eksperimen dan anak kelas kontrol menerapkan metode konvensional. Penarikan sampel dalam penelitian ini menggunakan teknik Cluster Sampling yang menetapkan kelas jedah sebagai eksperimen dan kelas mekah sebagai kelas kontrol untuk memperoleh data penelitian, penelitian menggunakan teknik tes sikap, observasi, dokumentasi, cek klis dan wawancara sedangkan teknik analisis data yang digunakan adalah uji t Independent-Sample $\mathrm{T}$ test dan uji Man-Whitney dengan Program Statistical Product and Service Solution (SPSS). Penelitian yang dilakukan menunjukkan hasil sebagai berikut tidak terdapat perbedaan yang signifikan antara keterampilan motorik kasar dan motorik halus anak kelas eksperimen dan kelas kontrol sebelum proses pembelajaran dan terdapat perbedaan yang signifikan antara keterampilan motorik kasar dan motorik halus anak kelas eksperimen dan kelas kontrol setelah proses pembelajaran.
\end{abstract}

Kata Kunci: pendekatan santifik, keterampilan motorik

\begin{abstract}
The gross and fine motor skills of children in learning at TK Al Kautsar Indralaya Ogan Ilir became the focus of this research departing from the reality in the field that the learning process in the kindergarten had not been explored simultaneously. The learning process was only concentrated on the cognitive aspects. This made the skills had not been maximumly achieved by the children. As the result, their gross and fine motor activities were less skilled. So, an alternative scientific approach was needed to meet the achievement of aspects of gross and fine motor skills. This study aims at finding out differences in children's gross and fine motor skills between the experimental class and control class before and after the children's learning process at TK Al Kautsar Indralaya Ogan Ilir. The design used in this study was Quasi Experimental Design Nonequivalent Control Group Design. In the implementation of the treatment, the children in the experimental class were given the Scientific Approach and the children in the control class were given conventional methods. In this study, Cluster Sampling technique was used by setting the classes, Jedah class as an experimental class and Mekah class as a control class to obtain research data. Then, the data gained were analyzed using Independent sample t-test and Man-Whitney test with Statistical Product and Service Solution (SPSS) Program. The research findings showed that there was no significant difference between gross and fine motor skills of the students in the experimental class and the students the control class before the learning process, but there was a significant difference between gross and fine motor skills of the students in the experimental class and the students in the control class after the learning process.
\end{abstract}

Key Words: Scientific Approach, Motor Skills 


\section{Pendahuluan}

Pendekatan saintifik adalah proses pembelajaran yang dirancang sedemikian rupa agar peserta didik secara aktif mengkonstruk kompetensi sikap, pengetahuan, dan keterampilan melalui tahapan mengamati, menanya, mengumpulkan informasi, menalar, dan mengkomunikasikan (Ditjen PAUDNI, 2014:15). Pendekatan saintifik tidak diartikan sebagai belajar sains tetapi menggunakan proses saintifik dalam kegiatan belajar. Pendekatan saintifik dalam membangun kemampuan berfikir lebih tinggi menunjukkan adanya tahapan yang berkembang dari proses menghafal, memahami, menganalisa dan menciptakan (Ditjen PAUDNI, 2014:22).

Pengenalan proses saintifik untuk Anak Usia Dini dilakukan dengan cara melibatkan anak langsung dalam kegiatan; yakni melakukan, mengalami pencarian informasi dengan bertanya, mencari tahu jawaban hingga memahami dunia dengan gagasan-gagasan yang mengagumkan (Yuliani, 2015:15). Pembelajaran Saintifik pada Anak Usia Dini merupakan hal yang sangat penting untuk banyak aspek perkembangan anak. Para peneliti menganjurkan pembelajaran saintifik mulai dikenalkan sebelum anak memasukki sekolah; bahkan anak sejak lahir. Hal ini penting untuk membantu anak memahami dunia, mengumpulkan dan mengolah informasi sebagai kunci dasar anak belajar berfikir saintifik (Ditjen PAUDNI, 2014:15).

Mengembangkan berfikir saintifik sejak usia dini akan mempermudah transfer keterampilan saintifik yang mereka miliki menjadi area akademik yang dapat mendukung prestasi akademik.

Penerapan pendekatan santifik pada pembelajaran di Pendidikan Anak Usia Dini diharapkan menjadi jawaban untuk merubah paradigma pendidikan dari teacher center menjadi student center. Pola pikir yang mengagap bahwa guru sebagai satu-satunya sumber belajar harus segera ditinggalkan, karena lingkungan dan ilmu pengetahuan serta teknologi sebagai kunci pembuka sumber belajar yang sangat luas (Ditjen PAUDNI, 2014:22). Belajar dilakukan dengan aktivitas aktif dimana anak melakukan banyak hal untuk mendapatkan pengalaman atau memperoleh informasi baru. Anak tidak lagi dianggap sebagai tokoh pasif yang hanya melakukan hal yang diperintahkan oleh pendidik, dimana anak tidak diberi kesempatan untuk menuangkan ide mereka, melakukan percobaan, dan berinteraksi dengan lingkungan.

Pada masa ini, anak mengalami tumbuh kembang yang luar biasa, baik dari segi fisikmotorik, emosi, kognitif maupun psikososial. Selain itu ditambah pula dengan kesenangannya dalam bereksplorasi dan seperti tak mengenal rasa takut, maka segala gerakan yang diajarkan pada anak akan dianggap sebagai satu permainan yang menyenangkan. Perkembangan anak berlangsung dalam proses yang holistik atau menyeluruh tidak hanya satu aspek perkembangan saja yang bisa dikembangkan secara optimal, namun seluruh aspek perkembangan anak seperti bahasa, kognitif, sosial emosional, fisik motorik, dan nilai-nilai agama dan moral, semuanya dapat berkembang secara optimal. Oleh kerena itu proses pembelajaran sebagai bentuk perlakuan yang diberikan pada anak harus memperhatikan karakteristik yang dimiliki setiap tahap perkembangan anak. 
Salah satu aspek yang penting dikembangkan pada usia dini adalah aspek perkembangan motorik. Perkembangan fisik motorik anak berperan sangat penting khususnya dalam lingkup pendidikan anak usia dini. Perkembangan motorik merupakan perkembangan pengendalian gerakan jasmaniah melalui kegiatan pusat syaraf, urat syaraf, dan otot yang terkoordinasi (Hurlock, 1997: 150). Perkembangan motorik meliputi perkembangan motorik kasar dan motorik halus. Motorik kasar merupakan gerakan yang menggunakan otot-otot besar seperti berjalan, berlari, melompat, dan lain sebagainya, sedangkan motorik halus merupakan gerakan yang menggunakan otot-otot halus seperti menulis, melipat, menggunting, menggambar dan lain sebagianya (Slamet, 2005: 51).

Berdasarkan pengamatan yang dilakukan selama melaksanakan P4 (Penerapan Pengembangan Perangkat Pembelajaran) di TK Al kautsar, terdapat data dari 15 anak, hanya $41,6 \%$ anak yang berkembang sesuai harapan. Sedangkan 58,3\% anak belum berkembang sesuai harapan anak yang memiliki keterampilan motorik kasar maupun halus yang belum berkembang dengan baik.

Anak kelompok B yang berada pada usia 5-6 tahun seharusnya sudah memiliki keterampilan motorik yang baik seperti yang bisa kita lihat dalam tingkat pencapaian fisik motorik anak pada kurikulum 2013 pendidikan anak usia dini misalnya Menggunakan anggota tubuh untuk pengembangan motorik kasar dan motorik halus, tetapi kenyataannya keterampilan motorik ini sering dilupakan oleh guru untuk di stimulasi sebagai hal yang paling penting untuk menunjang anak dalam hal percaya diri.

Berdasarkan pengamatan yang dilakukan menunjukkan kemampuan motorik yang dimiliki anak masih belum terstimulasi secara optimal. Hal ini ditandai sebagian anak yang belum mampu melakukan gerakan motorik kasar maupun motorik halus seperti mempergunakan kedua tangan untuk mengerjakan tugas, memegang benda dengan satu tangan dan menggunakan gunting untuk memotong bentuk-bentuk sederhana, melipat sederhana, meremas, mencetak, dan kegiatan lainnya begitupun dengan motorik kasar ketidak mampuan anak melakukan kegiatan fisik, gerakan senam yang belum sempurna.

Melihat kondisi itu penulis merasakan perlunya dilakukan penelitian menggunakan salah satu pendekatan pembelajaran di TK yaitu pendekatan saintifik dalam pengembangan keterampilan motorik anak.

\section{Kajian Literatur}

Pendekatan adalah konsep dasar yang mewadahi, menginspirasi, menguatkan, dan melatari pemikiran tentang bagaimana metode pembelajaran diterapkan berdasarkan teori tertentu (Hamruni, 2012:6). Saintifik berasal dari bahasa Inggris yang berarti ilmiah, yaitu bersifat ilmu, secara ilmu pengetahuan atau berdasarkan ilmu pengetahuan. Pendekatan saintifik adalah proses pembelajaran yang dirancang sedemikian rupa agar peserta didik secara aktif mengkonstruk kompetensi sikap, pengetahuan, dan keterampilan melalui tahapan mengamati, menanya, mengumpulkan informasi, menalar, dan mengkomunikasikan (Ditjen PAUDNI, 2014:15). Dengan demikian, maka 
pendekatan saintifik dalam pebelajaran yang dimaksud disini adalah bagaimana metode pembelajaran diterapkan berdasarkan teori ilmiah.

Maxim (1993) menyatakan bahwa aktifitas fisik akan meningkatkan pula rasa keingintahuan anak dan membuat anak-anak akan memperhatikan benda-benda, menangkapnya, mencobanya, melemparkannya atau menjatuhkannya, mengambil, mengocok-ngocok, dan meletakkan kembali benda-benda kedalam tempatnya. Adanya kemampuan/keterampilan motorik anak juga akan menumbuhkan kreativitas dan imajinasi anak yang merupakan bagian dari perkembangan mental anak. Dengan demikian, sering pula para ahli menekankan bahwa kegiatan fisik dan juga keterampilan motorik anak akan dapat meningkatkan kemampuan intelektual anak. Belahan otak kiri akan mengatur cara berpikir logis dan rasional, menganalisis, bicara serta berorientasi pada waktu dan hal-hal terperinci, sedangkan belahan otak kanan berperan mengatur hal-hal yang intuitif, bermusik, menari, dan kreativitas.

Penelitian Erni Munastiwi dalam al Athfal Jurnal Pendidikan Anak Vol. 1 nomor 2 Tahun 2015 yang berjudul "Implementasi Pendekatan Saintifik Pada Pembelajaran Anak Usia Dini', pembelajaran yang dikelola baik sesuai kebutuhan dan karakteristik anak, dapat mengoptimalkan potensi kecerdasan yang dimiliki anak sejak dini. Proses pembelajaran merupakan sarana untuk menstimulasi potensi kecerdasan anak. Oleh karena itu, pemilihan metode, strategi, media dan pendekatan dalam proses pembelajaran harus sesuai tema dan materi pembelajaran. Pembelajaran dengan pendekatan saintifik dapat membangun kreativitas, imajinasi, dan gagasan yang dapat mengembangkan nilai agama dan moral, motorik, kognitif, bahasa, sosial emosional dan seni.

Tri utami (2016), dalam jurnal: Penerapan Pendekatan Saintifik dalam Upaya Penanaman Kompetensi Inti Anak Usia Dini di PAUD Terpadu An-Nur Yogyakarta. Hasil penelitiannya menujukkan bahwa penerapan pendekatan saintifik dilakukan melalui 5 tahap atau kegiatan meliputi (1) mengamati yaitu menyajikan benda atau objek nyata dari tema yang dibahas untuk diamati oleh anak menggunakan semua indranya; (2) menanya yaitu memberikan kesempatan kepada semua anak untuk menanyakan hal-hal yang menarik rasa ingin tahu mereka mengenai topik yang menjadi pembahasan; (3) mengumpulkan informasi yaitu melakukan percobaan sederhana untuk membuktikan pertanyaan yang diajukkan oleh anak dan mengumpulkan informasi mengenai topik yang dibahas dari berbagai sumber; (4) menalar yaitu mendiskusikan untuk membuat kesimpulan mengenai topik yang dibahas dan menggabungkan antara pengetahuan yang dimiliki anak dengan pengetahuan baru yang diperoleh; (5) mengkomunikasikan yaitu mengkomunikasikan pengetahuan yang diperoleh baik melalui bahasa /cerita dan juga hasil karya.

Penelitian lain yang berkaitan dengan metode saintifik adalah penelitian yang dilakukan oleh Hope K. et al. ( 2013) yang tertulis pada jurnal yang berjudul Using the Scientific Method to Guide Learning: An Integrated Approach to Early Childhood Curriculum. Jurnal yang ditulis oleh Hope K. Gerde, Rachel E. Schachter, Barbara A. Wasik menjabarkan tentang penelitian terkini mengenai metode ilmiah dan memberikan 
saran untuk menerapkan metode saintifik dalam kegiatan pembelajaran. Menggunakan metode saintifik untuk mengeksplorasi ilmu bagi anak-anak dalam pengamatan, mempertanyakan, memprediksi, bereksperimen, meringkas, dan berbagai hasil. Proses ini akan mendorong kemampuan anak-anak wawasannya sendiri berkenaan dengan orang-orang tersebut dalam bahasanya dan dalam peristilahannya.

I Nyoman Sumasa, A. A. I. N Marheani, Nyoman Dantes, program pascasarjana Universitas Pendidikan Ganesha program studi pendidikan dasar, tahun 2015, dengan judul jurnal "Pengaruh Implementasi Pendekatan Saintifik terhadap motivasi Belajar dan hasil Belajar Bahasa Indonesia pada siswa kelas VI disekolah dasar segugus VI kecamatan Abang, Karang Asem”. Dalam tesis ini menjelaskan bahwa pendekatan saintifik Terdapat pengaruh motivasi belajar bahasa Indonesia antara siswa yang mengikuti pelajaran dengan pendekatan saintifik dan siswa yang belajar dengan model pembelajaran konvensional.

Anastasia Endah Anastika Dewi, program Universitas Negeri Yogyakarta studi pendidikan IPS, tahun 2016, dengan judul jurnal "Implementasi Pendekatan Saintifik dalam Pembelajaran IPS di Middle Grade SD tumbuh 3 kota Yogyakarta”, Dalam jurnal ini menjelaskan bahwa: (1) Implementasi pendekatan saintifik meliputi sudah sesuai kurikulum dan, pelaksanaan sesuai tahapan pendekatan saintifik, penilaian belum sesuai penilaian otentik, tindak lanjut sudah sesuai. (2) Penerapan pendekatan saintifik pada pembelajaran IPS untuk siswa middle grade sesuai dengan perkembangan berfikir dan proses belajar siswa. (3) Faktor pendukung pendekatan saintifik adalah: kepala sekolah, guru yang profesional, iklim sekolah yang kondusif, sarana dan prasarana yang lengkap.

\section{Metodologi Penelitian}

Jenis penelitian adalah penelitian lapangan (field research, pendekatan yang digunakan dalam penelitian ini adalah pendekatan kuantitatif.metode penelitian yang digunakan dalam penelitian ini adalah eksperimen kuasi dengan pola Nonequivalent Control Group Design (pre test-pos test yang tidak ekuivalen). Adapun gambaran mengenai rancangan Nonequivalent Control Group Design (Sugiono, 2007:116). Penarikan sampel dalam penelitian ini menggunakan teknik Cluster Sampling yang menetapkan kelas jedah sebagai eksperimen dan kelas mekah sebagai kelas kontrol untuk memperoleh data penelitian, penelitian menggunakan teknik tes sikap, observasi, dokumentasi, cek klis dan wawancara sedangkan teknik analisis data yang digunakan adalah uji $\mathrm{t}$ Independent-Sample $\mathrm{T}$ test dan uji Man-Whitney dengan Program Statistical Product and Service Solution (SPSS).

\section{Hasil dan Pembahasan}

Dalam penelitian ini yang dijadikan ukuran dan kriteria untuk menilai ada atau tidaknya perbedaan antara keterampilan motorik kasar dan halus anak sebelum menerapkan pendekatan santifik dan kelas kontrol yang tidak diajarkan dengan 
pendekatan saintifik adalah perbedaan mean atau Mean Differences. Hal ini diperkirakan akan timbul sebagai akibat dari perbedaan perlakuan. Selanjutnya untuk menilai apakah perbedaan mean itu cukup menyolok, cukup berarti, atau cukup menyakinkan atau tidak, digunakan teknik-teknik statistik yang khusus dipersiapkan untuk menilai ada tidaknya perbedaan.

\section{Deskripsi Data Pre-Test}

Hasil dari analisis melalui uji descriptive statistics frequencies pada program SPSS sebagaimana yang didapat, menunjukkan bahwa skor pre-test keterampilan motorik kasar anak kelas eksperimen berasal dari respoden sebanyak 15 anak, diperoleh nilai rata-rata sebesar 52.07, standar deviasi (simpangan baku) sebesar 6.627, nilai terendah 41, nilai tertinggi 66, dan jumlah sebesar 781.

Hasil dari analisis melalui uji descriptive statistics frequencies pada program SPSS sebagaimana yang didapat, menunjukkan bahwa skor pre-test keterampilan motorik halus anak kelas eksperimen berasal dari respoden sebanyak 15 anak, diperoleh nilai rata-rata sebesar 53.2, standar deviasi (simpangan baku) sebesar 15.23, nilai terendah 37, nilai tertinggi 72, dan jumlah sebesar 798 .

Hasil dari analisis melalui uji descriptive statistics frequencies pada program SPSS sebagaimana yang terdapat pada tabel yang didapat, menunjukkan bahwa skor pre-test keterampilan motorik kasar anak kelas kontrol berasal dari respoden sebanyak 15 anak, diperoleh nilai rata-rata sebesar 53.66, standar deviasi (simpangan baku) sebesar 10.25, nilai terendah 37, nilai tertinggi 69, dan jumlah sebesar 805 .

Hasil dari analisis melalui uji descriptive statistics frequencies pada program SPSS sebagaimana yang didapat, menunjukkan bahwa skor pre-test keterampilan motorik halus anak kelas kontrol berasal dari respoden sebanyak 15 anak, diperoleh nilai rata-rata sebesar 59.46, standar deviasi (simpangan baku) sebesar 11.17, nilai terendah 53, nilai tertinggi 75, dan jumlah sebesar 889.

\section{Deskripsi data post-test}

Hasil dari analisis melalui uji descriptive statistics frequencies pada program SPSS sebagaimana yang didapat, menunjukkan bahwa skor post-test keterampilan motorik kasar anak kelas eksperimen berasal dari respoden sebanyak 15 anak, diperoleh nilai rata-rata sebesar 77.93, standar deviasi (simpangan baku) sebesar 8.27, nilai terendah 66, nilai tertinggi 91, dan jumlah sebesar 1.169.

Hasil dari analisis melalui uji descriptive statistics frequencies pada program SPSS sebagaimana yang didapat, menunjukkan bahwa skor post-test keterampilan motorik kasar anak kelas eksperimen berasal dari respoden sebanyak 15 anak, diperoleh nilai rata-rata sebesar 74.93, standar deviasi (simpangan baku) sebesar 13.26, nilai terendah 50, nilai tertinggi 94, dan jumlah sebesar 1.124.

Hasil dari analisis melalui uji descriptive statistics frequencies pada program SPSS sebagaimana yang didapat, menunjukkan bahwa skor pre-test keterampilan motorik kasar anak kelas kontrol berasal dari respoden sebanyak 15 anak, diperoleh 
nilai rata-rata sebesar 59.46, standar deviasi (simpangan baku) sebesar 11.17, nilai terendah 47, nilai tertinggi 69, dan jumlah sebesar 892.

Hasil dari analisis melalui uji descriptive statistics frequencies pada program SPSS sebagaimana yang didapat, menunjukkan bahwa skor pre-test keterampilan motorik kasar anak kelas eksperimen berasal dari respoden sebanyak 15 anak, diperoleh nilai rata-rata sebesar 59, standar deviasi (simpangan baku) sebesar 65.33, nilai terendah 53, nilai tertinggi 75, dan jumlah sebesar 889 .

3.

Analisi data pre-test

Pada grafik Normal Q-Q Plot pada pre-test keterampilan motorik kasar anak kelas ekperimen, terlihat bahwa data menyebar dekat dengan garis lurus atau data tersebut di sekelilingi garis lurus. Jadi dapat dinyatakan bahwa data yang diuji berdistribusi normal.

Pada grafik Normal Q-Q Plot pada pre test keterampilan motorik kasar anak kelas kontrol, terlihat bahwa data menyebar data menyebar dekat dengan garis lurus atau data tersebar di sekeliling garis lurus (kecuali ada dua data yang tidak outlier). Jadi masih dapat dinyatakan bahwa data yang diuji berdistribusi normal.

Berdasarkan hasil pengujian pada tabel Test of Homogeneity of Variancesdiperoleh signifikansi 0,119. Ternyata nilai signifikansi 0,119>0,05, dengan demikian data pre-test keterampilan motorik kasar anak kelas eksperimen dan kelas kontrol di atas dinyatakan homogen. Maka dapat dikatakan data berasal dari populasipopulasi yang mempunyai varians sama.

Pada grafik Normal Q-Q Plot pada pre-test keterampilan motorik halus anak kelas ekperimen di atas, terlihat bahwa data menyebar dekat dengan garis lurus atau data tersebut di sekeliling garis lurus. Jadi dapat dinyatakan bahwa data yang diuji berdistribusi normal.

Pada grafik Normal Q-Q Plot pada pre test keterampilan motorik halus anak kelas kontrol di atas, terlihat bahwa data menyebar dekat dengan garis lurus atau data tersebar di sekeliling garis lurus. Jadi masih dapat dinyatakan bahwa data yang diuji berdistribusi normal.

Berdasarkan hasil pengujian pada tabel Test of Homogeneity of Variancesdiperoleh signifikansi 0,159. Ternyata nilai signifikansi $0,159<0,05$, dengan demikian data pre-test keterampilan motorik halus anak kelas eksperimen dan kelas kontrol di atas dinyatakan homogen.

4.

Analisi data post-test

Pada grafik Normal Q-Q Plot pada post-test keterampilan motorik kasar anak kelas ekperimen, terlihat bahwa data menyebar dekat dengan garis lurus atau data tersebut di sekeliling garis lurus. Jadi dapat dinyatakan bahwa data yang diuji berdistribusi normal.

Pada grafik Normal Q-Q Plot pada post test keterampilan motorik kasar anak kelas kontrol di atas, terlihat bahwa data menyebar dekat dengan garis lurus atau data 
tersebar di sekeliling garis lurus (kecuali ada dua data yang tidak outlier). Jadi masih dapat dinyatakan bahwa data yang diuji berdistribusi normal.

Berdasarkan hasil pengujian pada tabel Test of Homogeneity of Variances

diperoleh signifikansi 1.000. Ternyata nilai signifikansi $1.000>0,05$, dengan demikian data post-test keterampilan motorik kasar anak kelas eksperimen dan kelas kontrol di atas dinyatakan homogen. Maka dapat dikatakan data berasal dari populasipopulasi yang mempunyai varians sama.

Dilihat hasil output uji hipotesis Pre-test keterampilan motorik kasar anak kelas eksperimen dan kelas kontrol diperoleh $t_{\text {hitung }}=5.142$. $\mathrm{t}_{\text {tabel }}$ untuk $\mathrm{a}=0,05$ dengan df 28 diperoleh $\mathrm{t}\left({ }^{1} / 2 \mathrm{a}, 28\right)=1,7011$, berarti $\mathrm{t}_{\text {hitung }}>\mathrm{t}_{\text {tabel }}(5.142>1,7011)$, dengan demikian $\mathrm{H}_{0}$ diterima. Jadi, dapat diinterpretasikan bahwa tidak terdapat perbedaan yang signifikan antara pre-test keterampilan motorik kasar kelas eksperimen dan kontrol.

Selisih beda rata-rata nilai post-test keterampilan motorik kasar anak kelas eksperimen dan kelas kontrol dapat dilihat pada tabel 2.7 mean difference sebesar 18.47 hasil ini didapat dari rata-rata nilai post-test keterampilan motorik kasar kelas eksperimen sebesar 77.93 dikurang dengan rata-rata nilai post-test keterampilan motorik kasar anak kelas kontrol sebesar 59.46. adapun selisih beda ratarata nilai post test keterampilan motorik kasar anak kelas eksperimen dan kelas kontrol dapat dilihat pada grafik berikut.

Pada grafik Normal Q-Q Plot pada post-test keterampilan motorik halus anak kelas ekperimen, terlihat bahwa data menyebar dekat dengan garis lurus atau data tersebut di sekeliling garis lurus. Jadi dapat dinyatakan pada grafik Normal Q-Q Plot pada pre test keterampilan motorik halus anak kelas kontrol di atas, terlihat bahwa data menyebar data menyebar dekat dengan garis lurus atau data tersebar di sekeliling garis lurus (kecuali ada satu data yang tidak outlier). Jadi masih dapat dinyatakan bahwa data yang diuji berdistribusi normal.

Berdasarkan hasil pengujian pada tabel di atas diperoleh signifikansi 0,439. Ternyata nilai signifikansi $0,439<0,05$, dengan demikian data post-test keterampilan motorik halus anak kelas eksperimen dan kelas kontrol di atas dinyatakan homogen.

Pada tabel, dapat dilihat hasil output uji hipotesis Post-test keterampilan motorik halus anak kelas eksperimen dan kelas kontrol diperoleh $t_{\text {hitung }}=2.106$. $t_{\text {tabel }}$ untuk $\mathrm{a}=0,05$ dengan df 28 diperoleh $\mathrm{t}(\mathrm{a}, 28)=1,7011$, berarti $\left.\mathrm{t}_{\text {hitung }}>\mathrm{t}_{\text {tabel }} 2.106>1,7011\right)$, dengan demikian $\mathrm{H}_{0}$ diterima. Jadi, dapat diinterpretasikan bahwa tidak terdapat perbedaan yang signifikan antara post-test keterampilan muwiik kasar kelas eksperimen dan kontrol.

Uji beda rata-rata post-test keterampilan motorik halus anak dilaksanakan dengan tujuan untuk mengetahui ada atau tidak ada perbedaan skor rata-rata post-test keterampilan anak kelas ekperimen dan kontrol. Berdasarkan harga $t_{\text {hitung }}$ lebih besar dibandingkan dengan $t_{\text {tabel }}(2.106>1,7011)$, berarti $\mathrm{H}_{\mathrm{o}}$ ditolak dan $\mathrm{H}_{\mathrm{a}}$ diterima atau hipotesis berbunyi bahwa ada perbedaan yang signifikan antara keterampilan motorik halus anak kelas eksperimen yang diajarkan dengan pendekatan saintifik dan kelas kontrol yang tidak diajarkan dengan pendekatan saintifik. 
Selisih beda rata-rata nilai post-test keterampilan motorik kasar anak kelas eksperimen dan kelas kontrol dapat dilihat pada gambar 2.10 mean difference sebesar 9.60 Hasil ini didapat dari rata-rata nilai post-test keterampilan motorik halus kelas eksperimen sebesar 74.93 dikurang dengan rata-rata nilai post-test keterampilan motorik halus anak kelas kontrol sebesar 65.33

\section{Kesimpulan}

Berdasarkan pada uraian dan analisis data hasil penelitian, maka dapat diambil kesimpulan sebagai berikut: Nilai keterampilan motorik kasar dan halus pada kelas kontrol tidak mengalami perbedaan yang signifikan dibandingkan dengan kelas eksperimen. Ditinjau dari skor pre-test keterampilan motorik kasar anak nilai rataratanya sebesar 53.33, dan skor pos-test nilai rata-ratanya sebesar 59.46. selanjutnya keterampilan motorik halus skor pre-test nilai rata-ratanya sebesar 60.46 dan nilai posttest dengan menggunakan metode konvensional rata-ratanya sebesar 65.33.Nilai keterampilan motorik kasar dan halus pada kelas eksperimen dengan menggunakan pendekatan saintifik mengalami perbedaan yang signifikan. Ditinjau dari skor pre-test keterampilan motorik kasar anak nilai rata-ratanya sebesar 52.06, dan skor pos-test setelah proses pembelajaran dengan menggunakan pendekatan saintifik mengalami perubahan sebesar 77.93. selanjutnya keterampilan motorik halus nilai pre -test didapat sebesar 53.02, dan nilai rata-rata pos-test setelah menggunakan pendekatan saintifik sebesar 74.93 .

Hasil belajar anak setelah penerapan pendekatan saintifik terdapat perbedaan. Hal ini terbukti pada hasil post-test keterampilan motorik kasar anak kelas eksperimen dan kelas kontrol hasil perhitungan $t_{\text {hitung }} \geq t_{\text {tabel. }}$ Nilai $t_{\text {hitung }} 5.142>t_{\text {tabel }} 1.7011$, maka terdapat perbedaan yang signifikan antara keterampilan motorik kasar anak kelas eksperimen dan kelas kontrol. Hasil posttest moterampilan halus anak kelas eksperimen dan kelas kontrol hasil perhitungan $t_{\text {hitung }} \geq \mathrm{t}_{\text {tabel. }}$. nilai $\mathrm{t}_{\text {hitung }} 2.106>\mathrm{t}_{\text {tabel }} 1.7011$, maka terdapat perbedaan yang signifikan antara keterampilan motorik kasar anak kelas eksperimen dan kontrol. 


\section{Daftar Pustaka}

Hurlock, E. (1980). Psikologi Perkembangan, Suatu Pendekatan Sepanjang Rentang Kehidupan. Jakarta: Erlangga.

Danim, S. (2011). Perkembangan Peserta Didik. Bandung: Alfabeta.

Djaali \& Muljono, P. (2007). Pengukuran dalam Bidang Pendidikan. Jakarta: Grasindo.

Daryanto \& Susjendro, H. (2014). Siap Menyongsong Kurikulum 2013, cet ke 1, Yogyakarta: Gava Medika.

Desmita. (2005). Psikologi Perkembangan, Bandung: PT Remaja Rosdakarya.

Ditjen PAUDNI. (2014). Kerangka Dasar dan Struktur Kurikulum 2013 PAUD. Jakarta: Kemendikbud.

Ditjen PAUDNI. (2014). Pedoman Pendekatan Saintifik. Jakarta: Kemendikbud.

Hamruni. (2012). Strategi Pebelajaran. Yogyakarta: Insan Madani.

Hasan M. I. (2005). Pokok-Pokok Statistik 1. Jakarta: Bumi Aksar.

Husdarta \& Kusmedi, N. (2010). Pertumbuhan dan Perkembangan Peserta Didik (Olahraga dan Kesehatan). Bandung: Alfabeta.

Latif. (2013). Orientasi Baru Pendidikan Anak Usia Dini. Jakarta: Kencana.

Sholehudin, M. (2007). Pembaharuan Pendidikan TK, Cet ke 3. Jakarta: Universitas Terbuka.

Nasution. (2009). Metode Reserch (Penelitian Ilmiah). Jakarta: Bumi Aksara.

Nugroho, Y.A. (2011). Olah Data dengan SPSS. Yogyakarta: Skripta Media Creative.

Nuraini, Y. (2015). Implementasi Kurikulum 2013 PAUD. Jakarta: Yayasan.

Nurani, S. Y. (2011). Konsep Dasar Pendidkan Anak Usia Dini. Jakarta: Indeks.

Padjrin, Padjrin. "Pola Asuh Anak Dalam Perspektif Pendidikan Islam". Jurnal Intelektualita: Keislaman, Sosial dan Sains 5, no. 1 (September 6, 2016): 1 14. Accessed January 28, 2019. http://jurnal.radenfatah.ac.id/index.php/intelektualita/article/view/720.

Sugiyono. (2010). Metode Penelitian Pendidikan: Pendekatan Kualitatif, Kuantitatif, dan $R \& D$. Bandung: Alfabeta. 